\title{
Attitude of Coastal Communities on Mangrove Forest Management: A Phenomenological Study from Bulukumba Regency, Indonesia
}

\author{
Rosmiati $^{1 *}$, Bakhrani A. Rauf ${ }^{2}$, Faizal Amir ${ }^{3}$ \\ ${ }^{1}$ Department of Environmental Science, Universitas Negeri Makassar \\ Makassar, Indonesia \\ Email: ashar1401 [AT] gmail.com \\ ${ }^{2}$ Department of Engineering, Universitas Negeri Makassar \\ Makassar, Indonesia \\ Email: bakhranirauf192 [AT] yahoo.com \\ ${ }^{3}$ Department of Engineering, Universitas Negeri Makassar \\ Makassar, Indonesia \\ Email: faizalamir64 [AT] unm.ac.id
}

\begin{abstract}
Mangrove forests play a vital role in the survival of humans, animals, and plants in coastal areas. However, in reality, the mangrove area is getting more and more damaged due to human activities. This study aims to explore the attitudes of coastal communities in managing sustainable mangrove forests in both production and ecological functions. The design used in this study is a qualitative design with a phenomenological approach that does not aim to seek generalization but to explore in-depth information about the attitudes of coastal communities towards mangrove forest management. This study involved 31 participants consisting of government officials to coastal communities. Data was collected through research instruments in the form of interviews, observations, and documentation. After the data is collected, it is then analyzed using an interactive analysis model. The results show that coastal communities in Bulukumba district, Indonesia, have realized the importance of mangrove forests. They have participated in managing the mangrove forest based on the direction of the local government, which has implemented the mangrove forest replanting program.
\end{abstract}

Keywords--- Attitude, Coastal, Community, Mangrove

\section{INTRODUCTION}

One of the essential issues in the environmental field today is the existence of Mangrove forests and their benefits for human life. About 14 to 15 million hectares of mangrove forests are spread across 124 countries, with the most significant land in developing countries, one of which is in Asia [1], [2]. Mangrove is often found in developing countries that have the potential to be more vulnerable to climate change. [3] describe that many countries are trying to protect their coastal communities from sea-level rise and tropical storms with programs to conserve, restore and replant mangrove forests.

Mangrove forests are one of the most valuable ecosystems globally because of the dual service of protecting the coast for the species that live there. However, many coastal and marine ecosystems are lost relatively short duration [4]. In addition, mangrove forests also experience a lot of pressure from various directions so that their land area continues to decrease [5]. Several factors that are considered as a threat to the existence of this sensitive ecosystem include (1) exploitation of resources, (2) sea-level rise and climate change, and (3) a governance system that does not contribute much.

No less important is the management of mangrove ecosystems which have been marginalized in the political agenda in many countries for a long time [6]. However, [7] provide good news that there has been so much pro-literacy related to mangrove forests around the world in the last two decades. Increased interest in this issue is driven by an increased scientific understanding of ecological and climate services and the socio-economic value of goods and services from these ecosystems [8].

Damage to mangrove forests in Indonesia is a serious problem that must be addressed immediately. Most of the damage to mangrove forests occurs because of the conversion of mangrove forests designated as agricultural land, plantations, residential areas, dock buildings, and various mining and other activities that increasingly live-in coastal regions (Konom et al., 2019). However, the contribution of these multiple conversions is still much smaller compared to the increasingly 
rampant shrimp and fish farming activities (Rosyidi, 2018).

In overcoming these problems, it is necessary to make efforts to reposition the involvement of local communities in their areas so that the development of the coastal regions can run effectively and efficiently. Communities living in coastal areas generally face almost the same problems related to poverty issues [9]. This community is a socio-cultural group with cultural roots built on a blend of maritime, coastal, and market-oriented cultures. This tradition has developed into a cosmopolitan, inclusive, egalitarian, dynamic, and entrepreneurial culture and attitude [10]. These factors lead to the birth of attitudes and behaviour of coastal communities towards environmental sustainability, especially mangrove forest ecosystems.

This study aims to explore the attitudes of coastal communities towards sustainable mangrove forest management in Bulukumba Regency, Indonesia. Several studies have been conducted by researchers related to the management of mangrove forests in Indonesia. The research themes are primarily associated with mangrove forest damage, rehabilitation efforts to mangrove forest populations located on the islands of Java, Sumatra, and Bali [11]-[16].

However, to the researcher's knowledge, very few studies are still related to mangrove forests located in South Sulawesi Province, especially in Bulukumba Regency. This needs to be done to find out the conditions and attitudes of the people in Bulukumba Regency in managing the mangrove forest around them. The researchers believe that the results of this study can contribute to the development and management of mangrove forests for local governments, environmentalists, and coastal communities.

\section{LITERATURE REVIEW}

\subsection{Mangrove Forest}

Mangrove forest is a natural resource that has an essential role in the coastal environment. This forest is a tropical forest that grows on the edge of land and sea to stabilize coastlines, protect people from storms, provide animal habitat, and store large amounts of carbon [17]. In general, mangrove forests function as a supporter of several forms of life, namely land animals, marine animals, and humans [18].

Mangrove forests can also be defined as forests located in the intertidal zone where the ocean, freshwater, and land merge at a point [19]. This forest is one of the most productive and complex ecosystems on earth because it grows under different environmental conditions from other regions [20]. This type of forest is stated as a representative characteristic of all continents near the coast due to several factors, namely: (1) being rich in biodiversity, (2) providing habitat for animals and plants, and (3) having a loose and wet soil structure [21].

Grove forests have three main functions: physical (ecological), biological, and economic [22]. The physical functions of mangrove forests include windbreaks, pollutant filters, wave barriers, flood control and prevention of seawater intrusion into the mainland. Furthermore, the biological function of this forest is as a spawning ground, nursery ground, and feeding ground for fish and another marine biota. Finally, the economic role of mangrove forests is as a producer of wood and food and medicine for humans.

In general, mangrove forests have two main functions, namely direct and indirect functions [23]. The use of mangrove forests as a source of firewood and wood for other purposes was identified as a direct benefit. On the other hand, the help of this forest is indirectly related to the ability of mangrove forests to absorb wave energy and as a buffer against incoming storms. In addition, [24] emphasized that the indirect benefits for mangroves include filtering water from sediments before flowing into the sea.

\subsection{Coastal Community}

The term "coastal" refers to the meaning of a unique and distinctive area in the context of a landscape which is a meeting place between land and sea [25]. Furthermore, the term community can be interpreted as a group of people who have similarities and differences [26]. Thus, a community or community is a group of people living in an area or village with similarities in culture, habits, and resources [27].

Another meaning of coastal communities is a group of people in specific communities who live together inhabiting coastal areas that form and have a distinctive culture related to their dependence on coastal resources [28]. Coastal communities are also defined as essential groups in a country that plays a vital role in ensuring food security and diversification of economic activities in rural areas [29].

Characteristics of coastal areas can be viewed from the biophysical aspects of the area, coastal space, sea, and the resources contained therein that are unique. During this time, coastal communities have long enjoyed the many benefits of beaches, work, food, and recreation. Globally, coastal communities are facing severe threats along with extreme climate 
change, sea-level rise, coastal inundation, and degradation of coastal resources [30]. In most developing countries, the factors that have the most negative impacts on coastal communities are climate change, rising sea levels, and human activities that trigger damage along with coastal areas [31].

\subsection{Concept of Attitude \& Behavior}

B. F. Skinner developed a behavioural theory in 1950 by using the concepts of "positive" and "negative" to control one's behaviour. Attitude refers to psychological and sociological concepts about how and why individuals make decisions[32]. Attitudes and beliefs of a person's behaviour can be measured in various ways. Several studies have stated that there is always "hope" for each individual to experience a change in behaviour for the better [33].

The theory that builds the concept of human behaviour consists of three main domains: knowledge, attitude, and practice [34]. The same thing was stated by experts who said that human attitudes have three main components, abbreviated as ABC, namely affect, behaviour, and cognition [35], [36]. In other words, attitudes have a cognitive component (beliefs and knowledge), an affective component (feelings \& emotions, and a behavioural component (tendencies that can influence how to act) [37].

In this concept, a new behaviour will occur if something is needed and causes a reaction called a stimulus. A stimulus can produce a specific response or behaviour [38]. [39] formulates that behaviour is a person's response or reaction to the stimulus he receives (stimulus from outside). This theory is called the Stimulus-Organism-Response (SOR) theory since behaviour occurs because of a stimulus to the organism, then the organism responds [40].

\section{METHODS}

\subsection{Research Design}

This study aims to explore the attitudes of coastal communities towards sustainable mangrove forest management. In line with this goal, the researcher used a qualitative research design with a phenomenological approach. In this approach, participants describe a concept or phenomenon they experience, and on the other hand, the researcher explains the general meaning of the phenomenon [41]. The main point in phenomenological studies is how to try to understand someone who experiences certain phenomena from the perspective of each person by entering their world [42]. In line with this statement, some experts claim that this study is designed to describe and interpret a person's journey by determining the meaning of the perceived experience [43], [44].

\subsection{Participants}

Participants involved in this research can be referred to as "research informants" consisting of key informants and ordinary informants. The selection of these participants used a purposive sampling technique by considering several reasons related to the study. The use of this sampling technique is usually to identify and select information-rich cases using limited resources [45], [46]. These participants were selected by considering several important aspects, namely: (1) informants have adequate knowledge about coastal community empowerment programs, (2) informants are people who are directly involved in the research focus, and (3) selected informants can provide information convincing.

Several other participants were then obtained from these key informants, commonly referred to as the snowball technique. This technique is a sampling method where one key informant interviewed recommends one or more potential names for further interview [47], [48]. In this study, the main informant was the Head of the Department of Marine Affairs and Fisheries, Bulukumba Regency, South Sulawesi, Indonesia. Furthermore, the participants of the snowball technique consisted of: (1) Head of Fisheries, Catching, Supervision and Protection of Kab. Bulukumba, (2) Section Head of Fishing and Control of Marine and Fishery Resources Kab. Bulukumba, (3) Section Head of Coastal Development, Spatial Planning and Counseling on Maritime Affairs and Fisheries Law Kab. Bulukumba, (4) Head of Manyampa Village, (5) Head of Ujung Loe Sub-district, Kab. Bulukumba, and (6) the community involved in protecting the mangrove area in Bulukumba. Thus, the total number of participants involved in this study were 31 people.

\subsection{Data Collection}

\subsubsection{Deep Interview}

One of the research instruments used in this research is a structured in-depth interview. This instrument is a flexible data collection tool because it can switch from one topic to another [49], [50]. This interview was conducted by asking open-ended questions that allowed the informant to provide broad answers. Questions are directed at the process of 
disclosing the informant's life, responses, perceptions, roles, activities, and events experienced concerning the focus under study.

\subsubsection{Observation}

Another instrument used in this research is observation. Observation is collecting data using one's senses by seeing and hearing systematically and meaningfully [51], [52]. Observations are carried out by observing the target or focus of research directly and recording events and behaviour in a natural, original, not artificial, and spontaneous manner within a specific time to obtain accurate, in-depth, and detailed data.

\subsubsection{Documentation}

In addition to interviews and observations, data collection was also carried out by collecting several documents. This documentation technique is carried out to obtain information and data by analyzing various documents that support the research theme [53]. The documents needed in this research are multiple laws and regulations that form the legal basis for the sustainable management of mangrove forest areas. In addition, other documents that are used to support this research are documents containing activity programs, archives, meeting minutes, and written reports directly related to sustainable management activities in mangrove forest areas.

\subsubsection{Data Analysis}

After collecting the data from the three research instruments above, the researcher analyzed the data using an interactive analysis model. This analysis is done by organizing the data into categories, breaking it down into units, synthesizing, compiling patterns, choosing what is essential and what will be studied, and drawing conclusions [54]. In general, there are three stages in this analysis model, namely: (1) data condensation, (2) data display, and (3) conclusion or verification [55].

Furthermore, in determining the accuracy of participants' responses to interview questions (credibility), the researchers used the member checking technique [56]. This technique is considered appropriate because it provides an opportunity for participants to examine or agree on certain aspects of the interpretation of the data they have provided during the interview process. In other words, participants were given a transcript of the interview results and then asked to edit, clarify, elaborate, and even delete sentences that they considered unnecessary in the transcript [57].

\section{RESEARCH RESULTS}

The following describes the results of interviews, observations, and document analysis on the behaviour of coastal communities towards mangrove forest management in Bulukumba Regency, South Sulawesi, Indonesia. In terms of maintaining and planting mangrove forests, coastal communities provide an overview of what they have been doing so far. The following are excerpts from interviews of researchers with farmer groups in coastal areas:

"We formed farmer groups and planted mangrove seedlings from the fruit. So, the mangrove area was expanded because we already felt the benefits. Currently, there is a seed distribution program from the Environment and Fisheries Service."

The following interview point relates to the description of the condition of the mangrove forest around them. Here are excerpts from the interview:

"We are willing to expand the mangrove forest because we have already felt the benefits. If the mangrove forest is extensive, the crabs and fish are also increasing. Currently, the mangrove area looks more beautiful and attractive. If a plant dies, we will plant it again."

From the two excerpts of the interview, information was obtained that coastal communities have shown great concern for the importance of conserving mangrove forests. One of them is planting new mangrove seedlings, expanding the mangrove forest area, and replanting if there are plants that die because they have realized the benefits. In addition, other findings state different things. Some coastal communities are less interested in planting mangrove seedlings. The following is an excerpt from the interview:

"I'm not in a farmer's group. So, I did not participate in planting mangrove forest seeds. From the Environment Agency, seeds have been prepared to be distributed to people who want to plant. So, we just have to plant it."

Regarding the role of the local government, in this case, controlled by the Fisheries and Marine Service of Bulukumba Regency, it strongly supports the Manyampa village program in sustainable mangrove forest management. This support is in the form of providing ready-to-plant mangrove seedlings. The following observations and interviews evidence this: 
"Incidentally, the program has been carried out twice. The first program was seeded from outside and was pretty good. Almost $100 \%$ of the seeds grow and live. But what we have just planted, as much as 40 thousand we take from local seeds from mangrove fruit around here. The seeds were collected by the community and then purchased by the South Sulawesi Provincial Fisheries Service. But we don't know whether this type of seed is good or not. It depends on how it grows in the future."

The descriptions above show that local people are more likely to plan to plant seeds to preserve the production function of mangrove forests. Regarding the production function of mangrove forests, most coastal communities use them as a source of livelihood. Some of the livelihood activities of these coastal communities include: (1) looking for shellfish, (2) looking for mud crabs, and (3) looking for mangrove roots that can be used as firewood and charcoal.

In addition, all respondents stated that mangrove forests provide many benefits, such as being used as a mangrove forest as a tourist attraction. In addition to tourist attractions, mangrove forests can also withstand abrasion and withstand strong sea waves. The following are the results of interviews with local people:

"There are many uses of mangroves, such as preventing abrasion and filtering organic materials that will enter the sea. Then, mangroves are also a place of refuge for marine organisms.",

The same thing was conveyed by the head of the farmer group "SIPAKATAU" when interviewed by the researcher. Here is an excerpt from his interview:

"I think mangroves have economic value, because with this mangrove forest there is protection for crabs, fish, and others."

Regarding the discourse of mangrove forest management by outsiders, coastal communities have their views. The mangrove forest located in Manyampa Village, Ujung Loe District, manages the local community's village funds. Thus, they disagree if outside parties want to take over the area, even though they only act as capital providers. The following is an excerpt from an interview with the local community:

"It can, actually it can be done, the important thing is that there is a commitment and agreement for the sharing of the results. Investing in shares means waiting for the results, but later if it is agreed with the community and the village head, it can be done. The problem is that all the results cannot be taken because the mangroves are the assets of Luppung Village."

"I think it's like this, why should you disagree if it's not detrimental. The most important thing is that it is mutually beneficial for both parties. The people of Luppung Village are willing to accept outside parties as partners on the condition that the investors are from within the country and not from abroad."

Furthermore, based on interviews from 25 respondents, only two people (8\%) agreed if there were outsiders to build mangrove forests as long as they were not destructive. On the other hand, 23 people from coastal communities (92\%) did not agree that this was done for various reasons. Some of the reasons they put forward include: (1) prohibited without permission from the government, (2) non-foreigners who take it, (3) increase village income, and (4) use villagers as partners to reduce unemployment.

After reviewing points about mangrove forest management, the researchers also explored information about community activities in utilizing mangrove forests. Most local people want to take advantage of the mangrove forest area by building small houses where they sell culinary delights. This is reinforced by the results of direct observations and interviews with the community:

"Now I have built two places to sell culinary. If there are those whose economy cannot afford it, they can enter and sell here."

From the interviews with 25 respondents from coastal communities, 18 people (72\%) stated that they had planned to use mangrove forests as culinary tourism spots. This is done by building small houses for selling. In addition, seven residents (28\%) stated that they did not plan to use the mangrove forest because they did not understand the benefits of the mangrove forest.

In general, these coastal communities make mangrove forest areas a source of livelihood. Based on interviews with 25 respondents (coastal communities), 22 people or $88 \%$, stated that mangrove forests were their source of livelihood. For example, during this mangrove forest tour, some people sell culinary delights to get income. In addition, coastal communities also use mangrove forests as a place to find crabs. Thus, the village's regional revenue (PAD) will increase. The following is an excerpt from an interview with the Manyampa Village Head:

"I don't think it's really a problem. So far, there are many forms and types of businesses that want to enter for investment, but the majority only invest. We prioritize the residents of Luppung Village to open businesses such 
as selling culinary so that they get additional income. We manage this mangrove forest from the village fund budget, so it must be earmarked for the residents of Luppung Village as well."

In addition to the results above, three coastal residents (12\%) state that they do not use mangrove forests as their source of livelihood. This is due to their evident ignorance of what type of business is suitable to be carried out in the mangrove forest area. So far, some of these residents have only planted it without knowing what benefits they can get from the existence of the mangrove forest. The descriptions above illustrate that the tendency of local communities to preserve the production function of mangrove forests is relatively high by using mangrove forests as a source of livelihood and increasing the income of village funds.

\section{DISCUSSION}

In general, coastal communities have shown great concern for the importance of conserving mangrove forests in their environment. Some of the activities they carry out include replanting mangrove seedlings, expanding the area, and replanting if a mangrove plant dies. This was done because they realized that mangrove forests are the backbone of food webs on the coast [58]. With good mangrove forest conditions, not only marine life habitats are maintained, but they also provide coastline protection for 123 countries in the world [59].

This study also confirms that the community has realized the benefits of mangrove forests for them. The existence of mangrove forests provides many benefits to coastal communities, both obtained through increasing fish catches, mangrove wood with a high export value, and beach security from abrasion and waves [60]. The community can use mangrove forest products, wood and non-timber products, such as construction materials, firewood, food, crafts, medicines, tourism, and much more [61]. Mangrove forests are currently recognized as hotspots in mitigating extreme climate change due to their ability to absorb and bury large amounts of anthropogenic carbon dioxide [62], [63].

Several studies have determined several benefits of mangrove forests for coastal communities, both socially, economically, and ecologically. A study states that coastal marine vegetation is a vital component of the livelihoods of coastal communities because it offers various social and economic values to surrounding communities [64], [65]. Ecologically, mangrove forests provide nurseries for marine species, nutrient cycling, seawater purification, and coastal stabilization [66].

Concerning local governments' efforts in conserving mangrove forests, the study results show that there are already programs being implemented. The provincial government's efforts strongly support the village program in sustainable mangrove forest management by assisting in the form of mangrove seeds ready to be planted. This action follows the mangrove management policy strategy, which aims to supervise and control mangrove management to be sustainable. Some of the objectives of monitoring and controlling the management of coastal areas include: (1) to ensure the implementation of integrated and sustainable management of coastal areas, (2) to detect deviations from the implementation of the strategic plan, (3) to encourage the use of resources in coastal areas, and (4) to enforce the law by imposing sanctions on violators in the form of administrative sanctions, civil sanctions, and criminal sanctions (Law No. 27 of 2007).

Although this study shows an encouraging picture of mangrove forests, several studies show the opposite data. Mangrove forests are believed to be decreasing due to shrimp farming, coastal development, and clear-cutting activities for timber production [67]. According to released data, from 1980 to 2005, nearly 35,600 square kilos of mangrove forest were destroyed [59], [68], [69]. A consensus also reinforces this condition that states around 200,000 square kilometres of mangrove forest cover globally. But today, more than 50,000 square kilometres or about a quarter of the original mangrove forest area has been destroyed [58].

\section{CONCLUSION}

This study shows that the community has understood the importance of the existence and benefits of mangrove forests that they have received so far. This is evidenced by the results of interviews and observations, which show that they have been actively involved in planting and managing mangrove forests. In addition, they expect that mangrove forest management is carried out independently by coastal communities with the help of local governments without involving foreign parties as investors. Regarding the contribution of the mangrove forest, most people have taken advantage of the existence of the mangrove forest to serve as a place to sell various culinary delights. The role of the government has also gone well by helping coastal communities to replant damaged mangrove forests. The provision of mangrove seeds and the purchase of seeds from the community can be categorized as appropriate and effective local government policies to preserve mangrove forests. This research is expected to consider policymakers (central and local governments) in managing mangrove forests by involving coastal communities. This aims to make the community feel bound and have a responsibility in managing mangrove forests. 


\section{REFERENCES}

[1] C. Giri, E. Ochieng, L. L. Tieszen, Z. Zhu, and A. Singh, "NoStatus and distribution of mangrove forests of the world using erath observation satellite data," Global Ecology and Biogeography, vol. 20, pp. 154-159, 2011, doi: 10.1111/geb.2011.20.issue-1.

[2] Food and agriculture Organization of the United nations (FAO), The world's mangroves 1980-2005 (FAO forestry paper 153). Rome, Italy: FAO, 2007.

[3] H. D. Kapuangan, M. Maryunani, S. Soemarno, and N. Harahap, "The sustainability of mangrove ecosystem and its implication for mangrove-based rural tourism development in southern Malang regency, East Java, Indonesia," IOSR Journal of Environmental Science, Toxicology and Food Technology (IOSR-JESTFT), vol. 10, no. 7, pp. 27-34, 2016, doi: 10.9790/2402-1007022734.

[4] S. S. Romanach et al., "Conservation and restoration of mangroves: Global status, perspectives, and prognosis," Ocean \& Coastal Management, vol. 154, pp. 72-82, 2018, doi: 10.1093/j.ocecoaman.2018.01.009.

[5] M. Getzner and M. S. Islam, "Ecosystem services of mangrove forests: Results of a meta-analysis of economic values," International Journal of Environmental Research and Public Health, vol. 17, no. 5830, pp. 1-13, 2020, doi: 10.3390/ijerph17165830.

[6] Z. N. Feka, "Sustainable management of mangrove forests in West africa: A new policy perspective," Ocean Coastal Management, vol. 116, pp. 341-352, 2015, doi: http://dx.doi.org/10.1016/j.ocecoaman.2015.08.006.

[7] I. Osemwegie, H. D. N'da, C. Stumpp, B. Reichert, and J. Biemi, "Mangrove forest characterization in Southeast Cote d'Ivoire," Open Journal of Ecological, vol. 6, pp. 138-150, 2016, doi: 10.4236/oje.2016.63014.

[8] Z. N. Feka and I. Morrison, "Managing mangroves for coastal ecosystems change: A decade and beyond of conservation experiences and lessons for and from West-central Africa," Journal of Ecology and The Natural Environment, vol. 9, no. 6, pp. 99-123, 2017, doi: 10.5897/JENE2017.0636.

[9] A. Cahaya, "Fisherman community in the coastal area: A note from Indonesian poor family," Procedia Economics and Finance, vol. 26, no. 1, pp. 29-33, 2015, doi: 10.1016/S2212-5671(15)00801-1.

[10]C. Kusmana and T. Sukwiwa, "Coastal community preference on the utilization of mangrove ecosystem and channelbar in Indramayu, Indonesia,” AACL Bioflux, vol. 11, no. 3, pp. 905-918, 2018.

[11] M. Nopiana, F. Yulianda, Sulistiono, and A. Fahrudin, "Condition of shore and mangrove area in the coastal area of karawang regency, indonesia," AACL Bioflux, vol. 13, no. 2, pp. 553-569, 2020.

[12] M. Mubarak, A. Nurhuda, Y. Badrun, and R. F. Syahputra, "relationship of coastline and mangrove area in West Rangsang-Indonesia,” Journal of Southwest Jiaotong University, vol. 55, no. 5, pp. 1-13, 2020.

[13] H. Gunawan, S. Sugiarti, and S. Iskandar, "Dynamics of mangrove community in revegetation area of karangsong, north coast of Indramayu District, West Java, Indonesia,” Biodiversitas, vol. 18, no. 2, pp. 659-665, 2017, doi: 10.13057/biodiv/d180230.

[14] A. Mulyadi and B. Amin, "Vegetation structure and mangrove ecosystem threats in the coastal zone of Dumai, Riau, Indonesia," International Journal of Applied Environmental Sciences, vol. 11, no. 3, pp. 785-798, 2016.

[15] H. Cerlyawati, S. Anggoro, and M. Zainuri, "Mangrove rehabilitation program in North Coast, Central Java-Indonesia (Case study in Regency of Brebes, Pemalang, and Demak)," Journal of Applied Environmental and Biological Sciences, vol. 7, no. 5, pp. 131-139, 2017.

[16] R. Seary, T. Spencer, M. Bithell, C. McOwen, and Y. Ota, "Defining mangrove-fisheries: A typology from the Perancak Estuary, Bali, Indonesia," PLoS ONE, vol. 16, no. 4, pp. 1-21, 2021, doi: 10.1371/journal.pone.0249173.

[17] M. J. J. Buncag, "Community-based mangrove forest management sustainability: The case of some Asian countries," International Journal of Sciences and Research, vol. 10, no. 4, pp. 918-926, 2021, doi: 10.21275/SR21420102808.

[18] H. N. Carter, S. W. Schmidt, and A. C. Rons, “An international assessment of mangrove management: Incorporation in integrated coastal zona management," Diversity Journal, vol. 7, no. 1, pp. 74-104, 2015, doi: 10.3390/d7020074.

[19]P. J. Hogarth, The biology of mangroves and seagrasses. Oxford University Press, $2015 . \quad$ doi: 10.1093/acprof:oso/9780198716549.001.001.

[20] C. D. Woodroffe, K. Rogers, K. L. McKee, C. E. Lovelock, I. A. Mendelssohn, and N. Saintilan, "Mangrove sedimentation and response to relative sea-level rise," Annual Review of Marine Science, vol. 8, pp. 243-266, 2016, doi: 10.1146/annurev-marine-122414-034025.

[21] C. Kuenzer, A. Bluemel, S. Gebhardt, T. V. Quoc, and S. Dech, "Remote sensing of mangrove ecosystems: A review," Remote Sensing, vol. 3, no. 5, pp. 878-928, 2011, doi: 10.3390/rs3050878.

[22] J. Chow, "Mangrove management for climate change adaptation and sustainable development in coastal zones," Journal of Sustainable Forestry, vol. 37, no. 2, pp. 139-156, 2018, doi: 10.1080/10549811.2017.1339615.

[23] H. H. Nguyen et al., "Monitoring changes in coastal mangrove extents using multi-temporal satellite data in selected communes, Hai Phong City, Vietnam," Forest and Society, vol. 4, no. 1, pp. 256-270, 2020, doi: $10.24259 /$ fs.v4i1.8486.

[24] M. Hema and P. I. Devi, "Factors of mangrove destruction and management of manrove ecosystems of Kerala, India," Journal of Aquatic Biology and Fisheries, vol. 2, no. 1, pp. 184-196, 2015.

[25] M. Gleason, ocean and coastal management. California: The Nature Conservancy California Coastal and Marine Program, 2018. 
[26] B. Ahmed, I. Kelman, H. K. Fehr, and M. Saha, "Community resilience to cyclone disasters in coastal Bangladesh," Sustainability (Switzerland), vol. 8, pp. 1-29, 2016, doi: 10.3390/su8080805.

[27]F. Krunger, G. Bankoff, T. Cannon, and L. Schipper, Cultures and disasters: Understanding cultural framings in disaster risk reduction. Abingdon, UK: Routledge, 2015.

[28] L. Nalefo, B. Bahtiar, and S. Salahuddin, "The study of dynamic of coastal resource community-based management in Wabula Village of Buton regency," Journal of Sustainable Development, vol. 11, no. 6, pp. 142-151, 2018, doi: 10.5539/jsd.v11n6p142.

[29] K. Idris, A. A. Samah, T. Suandi, B. A. Samah, M. Muhammad, and H. A. M. Shaffril, "The coastal community views on the environmental changes," International Journal of Academic Research in Business and Social Sciences, vol. 7 , no. 2, pp. 2222-6990, 2017, doi: 10.6007/IJARBSS/v7-i2/2642.

[30] J. Ankrah, "Coastal community's perception on climate change and its impacts: Analysis of local coastal community of Winneba, Ghana," Asian Research Journal of Arts \& Social Sciences, vol. 12, no. 1, pp. 43-55, 2020, doi: 10.9734/arjass/2020/v12i130183.

[31] P. Shah, S. T. M. Dissanayake, Y. Fujita, and P. A. L. D. Nunes, "Impact of a local, coastal community based management regime when defining marine protected areas: Empirical results from a study in Okinawa, Japan," PLoS ONE, vol. 14, no. 3, pp. 1-17, 2019, doi: 10.1371/journal.pone.0213354.

[32]D. Sugandini, I. Rahatmawati, and R. Arundati, "Environmental attitude on the adoption decision Mangrove conservation: An empirical study on communities in special region of Yogyakarta, Indonesia," Review of Integrative Business and Economics Research (RIBER), vol. 7, no. 1, pp. 266-275, 2017.

[33] I. Ajzen and M. Fishbein, "The influence of attitudes on behavior," in The handbook of attitudes, D. Albarracin, B. T. Johnson, and M. P. Zanna, Eds. New Jersey: Lawrence Erlbaum Association, 2005.

[34] R. M. Bergner, "What is behavior? And so what?," New Ideas in Psychology, vol. 28, no. 1, pp. 1-9, 2010.

[35] A. H. Eagly and S. Chaiken, The psychology of attitudes. Fort Worth: Harcourt Brace Jovanovich, 1993.

[36] H. Van den Berg, "The impact of affective and cognitive facus on attitude formation," Journal of Experimental Social Psychology, vol. 42, no. 1, pp. 373-379, 2006.

[37] T. Marcinkowski and A. Reid, "Reviews of research on the attitude-behavior relationship and their implications for future environmental education research," Environmental Education Research, vol. 25, no. 4, pp. 459-471, 2019, doi: 10.1080/13504622.2019.1634237.

[38] S. Notoatmojo, Ilmu perilaku kesehatan. Jakarta, Indonesia: Rineka Cipta, 2010.

[39] J. Uher, "What is behaviour? and (when) is languange behaviour? A metatheoretical definition," Journal for The Theory of Social Behaviour, vol. 46, no. 4, pp. 475-501, 2016, doi: 10.1111/jtsb.12104.

[40] B. Liu, S. M, G. Young, S. Cheng, and M. Li, “Atimulus organism response model based analysis on consumers'online impulse buying behavior," The International Journal of Electrical Engineering \& Education, pp. 1-15, 2020, doi: 10.11/0020720920940585

[41] J. W. Creswell, Qualitative inquiry \& research design: Choosing among five approaches. USA: SAGE, 2013.

[42] R. B. Johnson and L. Christensen, Educational research: Quantitative, qualitative, and mixed approaches. USA: SAGE, 2014.

[43] D. Ary, L. C. Jacobs, A. Razavieh, and C. Sorensen, Introduction to research in education. Belmont, CA: Thompson \& Wadsworth, 2007.

[44]F. Özüdo, "Turkish preservice teachers ' experiences with emergency remote teaching: A phenomenological study," Issues in Educational Research, vol. 31, no. 1, pp. 166-187, 2021.

[45] L. A. Palinkas, S. M. Horwitz, C. A. Green, J. P. Wisdom, N. Duan, and K. Hoagwood, "Purposeful sampling for qualitative data collection and analysis in mixed method implementation research," Administration and Policy in Mental Health, vol. 42, no. 5, pp. 533-544, 2015, doi: 10.1007/s10488-013-0528-4.

[46] J. W. Creswell and V. L. Plano-Clark, Designing and conducting mixed methods research. London: Sage Publications, 2007.

[47] J. Kirchherr and K. Charles, "Enhancing the sample diversity of snowball samples: Recommendations from aresearch project on anti-dam movement in Southeast Asia," PLoS ONE, vol. 13, no. 8, pp. 1-17, 2018, doi: 10.1371/journal.pone.0201710.

[48] M. Naderifar, H. Goli, and F. Ghaljaie, "Snowball sampling: A purposeful method of sampling in qualitative research," Strides in Development of Medical Education, vol. 14, no. 3, pp. 1-6, 2017, doi: 10.5812/sdme.67670.

[49] L. Cohen, L. Manion, and K. Morrison, Research methods in education. Abingdon: Routledge, 2011.

[50] G. Ryan and H. Bernard, “Techniques to identify themes," Field Methods, vol. 15, no. 1, pp. 85-109, 2003.

[51]B. Smit and A. J. Onwuegbuzie, "Observations in qualitative inquiry: When what you see is not what you see," International Journal of Qualitative Methods, vol. 17, no. 1, pp. 1-13, 2018, doi: https://doi.org/10.1177/1609406918816766.

[52] L. E. F. McKechnie, "Observational research," in The Sage encyclopedia of qualitative research, L. M. Given, Ed. Thousand Oaks: Sage, 2008.

[53]H. K. Mohajan, "Qualitative research methodology in social sciences and related subjects," Journal of Economic Development, Environmental and People, vol. 7, no. 1, pp. 23-48, 2018. 
[54] M. B. Miles and A. M. Huberman, An Expanded Sourcebook-qualitative Data Analysis. London: Sage Publications, 1994.

[55]K. Bargate, “Interactive Qualitative Analysis - A Novel Methodology for Qualitative Research," Mediterranean Journal of Social Sciences, vol. 5, no. 20, pp. 11-19, 2014, doi: 10.5901/mjss.2014.v5n20p11.

[56] J. M. Morse, M. Barret, M. Mayan, K. Olson, and J. Spiers, "Verification strategies for establishing reliability and validity in qualitative research," International Journal of Qualitative Methods, vol. 1, no. 2, pp. 1-9, 2002.

[57] J. A. Carlson, “Avoiding Traps in Member Checking," The qualitative Reportualitative Report, vol. 15, no. 5, 2010.

[58] H. N. Carter, S. W. Schmidt, and A. C. Hirons, “An international assessment of mangrove management: Incorporation in integrated coastal zone management," Diversity, vol. 7, pp. 74-104, 2015, doi: 10.3390/d7020074.

[59] M. D. Spalding, M. Kainuma, and L. Collins, World atlas of mangroves. Washington: Earthscan Ltd, 2010.

[60]D. G. Bengen, Menuju pembangunan pesisir dan lautan berkelanjutan berbasis ekosistem. Bogor: P4L, 2004.

[61] A. Kustanti, Manajemen hutan mangrove. Bogor, Indonesia: IPB Press, 2011.

[62] L. M. Schile, J. B. Kauffman, S. Crooks, J. W. Fourqurean, J. Glavan, and J. P. Megonigal, "Limits on carbon sequestration in arid blue carbon ecosystem," Ecological applications, vol. 27, no. 3, pp. 859-874, 2017.

[63] C. M. Duarte, I. J. Losada, I. E. Hendriks, I. Mazarrasa, and N. Marba, "The role of coastal plant communities of climate change mitigation and adaptation," Nature Climate Change, vol. 3, pp. 961-968, 2013.

[64]L. Cullen-Unsworth and R. Unsworth, "seagrass meadows, ecosystem services, and sustainability," Environment International, vol. 55, no. 3, pp. 14-28, 2013.

[65] R. Costanza, R. De-Groot, and P. Sutton, "Changes in the global value of ecosystem services," Global Environmental Change, vol. 26, no. 1, pp. 152-158, 2014.

[66] A. A. Nchimbi and L. D. Lyimo, "Socioeconomic determinants of mangrove exploitation and seagrass in Zanzibar: Implications for sustainable development," Journal of Marine Biology, vol. 2019, pp. 1-11, 2019, doi: $10.1155 / 2019 / 7684924$.

[67] N. Z. Feka, G. B. Chuyong, and G. N. Ajonina, "Sustainable utilization of mangroves using improved fish-smoking systems: A management perspective from the Douala-Edea wildlife reserve, Cameroon," Tropical Conservation Science, vol. 2, no. 4, pp. 450-468, 2009, doi: 10.1177/194008290900200406.

[68] P. J. Hogarth, The biology of mangroves. New York: Oxford University Press, 1999.

[69] A. M. Ellison and E. J. Farnsworth, "Mangrove communities," in Marine community ecology, M. D. Bertness, S. D. Gaines, and M. E. Hay, Eds. New York: Sinaver Association, 2000. 